\title{
XLV. Project for the establishment of telegraphs on a new construction
}

\section{Capt. Pasley}

To cite this article: Capt. Pasley (1808) XLV. Project for the establishment of telegraphs on a new construction, Philosophical Magazine Series 1, 29:116, 292-296, DOI:

$10.1080 / 14786440808563743$

To link to this article: http://dx.doi.org/10.1080/14786440808563743

曲 Published online: 18 May 2009.

Submit your article to this journal \lceil

Џ Article views: 2

Q View related articles $\sqsubset$ 
inventor, soliciting him to describe and delineate the machine, so as it might be introduced into general use in the various quarters of the kingdom.

To save time in complying with these requests, he adopted the method of printing and circulating these plates, accompanied with a description, which will clearly demonstrate, at how very small an expense, and with how very little mechanical art, the elastic frame can be constructed; for, in fact, there is no village in Britain, in which an ordinary smith and carpenter reside, where it may not be easily made.

Under thęse circumstances, the inventor feels it a duty he owes to his country, and to those suffering bodily distress, to give it all the publicity in his power; with which view, and wirh the most ardent wishes for its continuing to prove beneficial, in mitigating the distresses of such as may require its aid, this account is submitted to the public.

Gayfield Place,

17 th Sept. 1807.

XLV. Project for the Lstallishment of Telegraphs on a New Construction. By CAPT. PAsuex, of the Royal Engineers.

[Concluded from p. 210.]

2d. A Polygrammatic Telegrath for Day Signals.

$I_{N}$ the reflections concerning the use of telegraphs in general, into which I was unavoidably led whilst digesting the above proposal, it appeared to me a fundamental principle of the art, to aim as much as possible at celerity and dispatch, which I found were in some measure to be gained by employing a number of words and sentences adapted to. the key of the telegraph, according to the method of sections, instead of adhering entirely to the tedious alphabetical mode, which (to the best of my knowledge) is the only one in common use.

Still there remained a defect, in its being impossible to express a variety of significations without making two or three 
three signals for each. The only remedy for this at first seemed to be, increasing the number of combinations of the telegraphs already established by adding more bodies, as, for instance, to construct an Admiralty telegraph with seven, eight, or nine bodies instead of six ; but this remedy is only partial, because additional bodies would run into confusion before the signal code can be enlarged to a sufficient extent.

On further consideration it therefore occurred to me, that it might be allowable to propose a new diurnal telegraph; and if my preceding observations are granted, I hope it may meet with approbation, being capable of exhibiting seven hundred and seven thousand two hundred and eighty distinct combinations, whereas no former one used in this country has exceeded sixty-three. I now proceed to describe the nature of the telegraph proposed, which, for the sake of distinguishing it from others on a more confined principle, I shall call the Polygrammatic Telegraph.

\section{Nature and Construction.}

Four upright posts are erected, each having two arms moveable on a spindle at top, which in their natural position hang down, but can be raised by means of strings to various degrees of extension, so as to appear in positions either vertical, horizontal, or inclined at an angle of $45^{\circ}$ with the horizon. The length of the arms may be about six feet from the centre of motion to the ends, or more, in proportion to the distance between the telegraphic stations. The strings will be worked by two men.

The combinations of two arms in the several positions enumerated are twenty-eight, of which a table is given in Plate VIII : eighteen of these are allotted to the alphabetical characters, and ten to the numerical ciphers, so that using the common mode of signal making, every post with its arms might form a complete telegraph, were it not the object of the present proposal to go further. A book is therefore made of words and sentences arranged in regular order, to the extent judged necessary, and let signal 2567 signify, for example, "The enemy have landed on the south-west coast," and let signal 9304 signify, " $A$ convoy is just arT 3 rived 
Plail.Mag. Vol.XXIX, Pl.VIII.

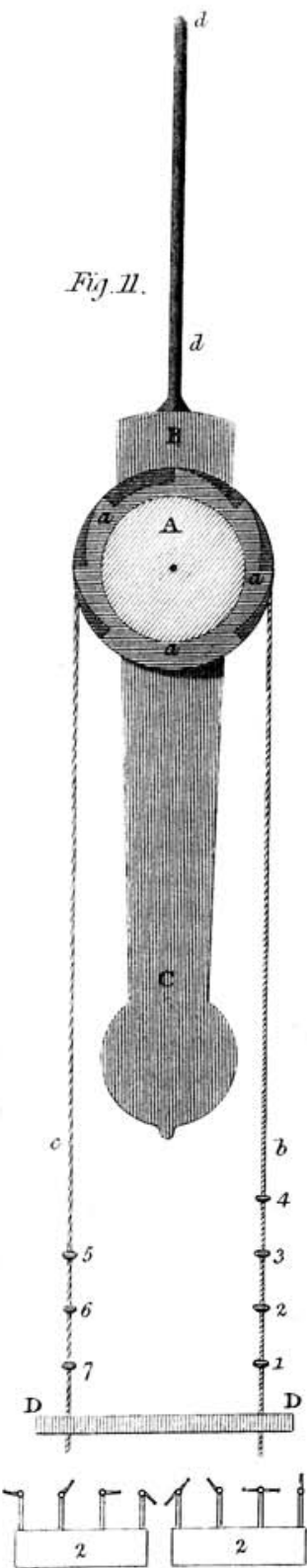

\begin{tabular}{|c|c|c|c|c|c|}
\hline \multicolumn{6}{|c|}{$\begin{array}{c}\text { TABIE of COMIBINATIONS, } \\
\not B E x^{\circ} \text { of the TELEGRAPWT. }\end{array}$} \\
\hline $\begin{array}{c}\text { Signat } \\
N_{0}^{\circ} \\
\end{array}$ & $\begin{array}{c}\text { Combination } \\
\text { shewn. }\end{array}$ & SHENIFICATTRVV & $\begin{array}{c}\text { sägnal } \\
N^{o}\end{array}$ & $\begin{array}{c}\text { Combination } \\
\text { shewn. }\end{array}$ & SGEVIFATION \\
\hline 1 & & 1 & 15 & & E \\
\hline 2 & & 2 & 16 & & F \\
\hline 3 & & 3 & 17 & & G \\
\hline 4 & & 4 & 18 & & H \\
\hline 5 & & 5 & 19 & & I, J, Y \\
\hline 6 & $\infty$ & 6 & 20 & & I \\
\hline 7 & & 7 & 21 & & M \\
\hline 8 & & 8 & 22 & & $\mathrm{~N}$ \\
\hline 9 & & 9 & 23 & & 0 \\
\hline 10 & & 10 imitial, 0 & 24 & & $\mathrm{P}$ \\
\hline 11 & 89 & A & 25 & & $\mathbf{R}$ \\
\hline 12 & 8 & B & 26 & & S,C soft,Z \\
\hline 13 & & $C$ hand, $K, Q$ & 27 & & $\mathbf{T}$ \\
\hline 14 & of & D & 28 & & $\mathrm{U}, \mathrm{V}, \mathrm{w}$ \\
\hline
\end{tabular}
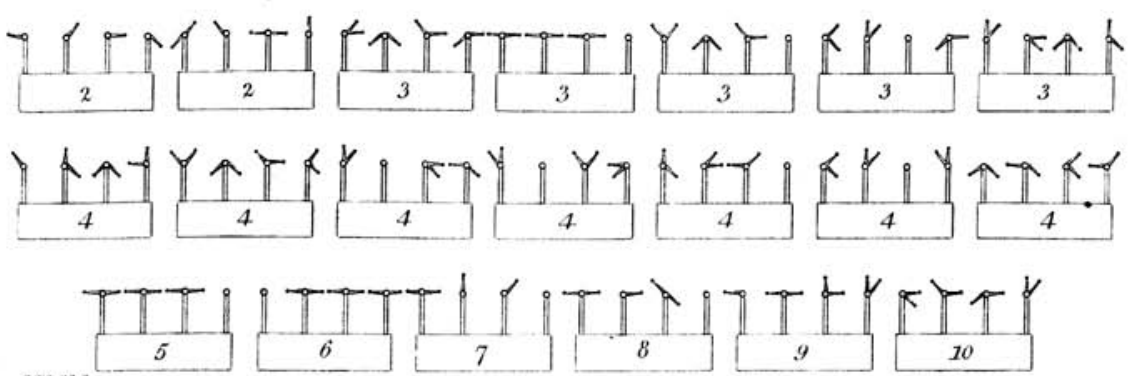
rived from the West Indies." Then these two picces of intclligence will be successively communicated by the two signals. Fig. 2, 2 .

But this telegraph has another property, 1 believe entirely new, of expressing words or parts of words not exceeding four letters, by a single signal. For instance, let it be required to communicate the following orders alphabetically : "Send 1000 men to Dover," or, "Three regiments will march to Leith:" the first will be cffected by five signals, and the second by seven, as in fig. 3, 3, 3, 3, 3, and 4, 4, 4, 4, $4,4,4$.

In working this telegraph no signal is required to denote the end:of a word, it being sufficient to mark a pause by leaving one of the posts in its quiescent state. And to distinguish between the numerical signals referring to the book or code, and such as are really intended to denote numbers, the unit place of the latter must never, but that of the former must always, be placed on the fourth or righthand post of the telegraph. Hence this post, when left quiescent between two numbers, will not be considered to denote a pause or break, as it would between two words. Thus, fig. 5 will signify one thousand, whilst fig. 6 will denote the 1000dth word or sentence in the book, and must be referred to there for its signification. Also, in consequence of the last remark, the signals 5 th, $6 \mathrm{th}, 7 \mathrm{th}$, and 8 th, the fig. $7,8,9,10$, will signify 104, 506, 820 pounds.

Observing this restriction, it will be found that a signal book may be formed, containing 10,999 words and sentences, if thought necessary, each to be expressed by one change on this telegraph, whilst all unforeseen intelligence can be communicated by an improved alphabetical mode, without these two methods interfering in the least with each other; so that I trust it will be allowed, that the object I had in view, namely, increased dispatch in signal making without loss of clearness or precision, is fully obtained.

C. Pasley, Capt. Royal Engineers. 
P. S. In describing the principles of the polygrammatic telegraph, I avoided entering into the minutix of its mechanical construction; by which, however varied, no fundamental part of the scheme can be affected. A model made by my directions in Malta proved to all whos saw it the practicability of the machine; I shall, in explanation, say a few words here, which will perhaps be almost equally satisfactory.

The under part of the posts is solid, but the upper part of them is composed of two side pieces with a space between, within which the arms play. One of the arms is represented in the annexed figure, (fig. 11,) hanging down in its natural position, so as to be entirely hid by the post when the telegraph is at rest. A roller $A$ is fixed to the arm near its head, having an iron ring $a, a, a$, screwed upon one side of it, and provided with grooves for the strings $b, c$, the ends of which are fastened to it in contrary directions. The other ends of these strings are bronght down into the signal room, and have seven knobs $(1,2,3,4,5,6,7$, fixed upon them, the intervals between which are proportioned to the circumference of the roller, in such a manuer that as they are respectively pulled down to the plane $D, D$, they will raise the arm by moving it on its pivot (which coincides with the centre of the roller) to the seven positions required in signal making. As the arm rises to any of these positions, the corresponding tooth of the ring $a$ a $a$ will be griped by one or other of two springs or catches fixed to the side pieces, which will hold it up in its proper position without fatigue to the men employed, till an order is given to prepare for a new signal. Then, by pulling another string, (not expressed in the figure,) the catches are drawn away from the teeth, and the arms being thus released fall down to their natural state. The same string, by a very simple contrivance, presses the arms down after the fourth position, and prevents their vibrating as they fall at the end of erery signal. $d d$ is a piece that would be invisible at the telegraphic distances, serving to increase the weight of the part $B$ as much as may be judged necessary. It was omitted in the model, as not being an essential pait of the machine in any other respeet. 
It has been already observed that one man is to work two posts ; the arms must therefore be so poised, by duly proportioning the weight of the part (B) above, and of the part (C) below the pivot, that he may with ease be able to raise two arms with each hand, the requisite preponderance of the lower part being at the same time preserved.

With regard to the signal houses chosen for this kind of telegraph, I have only to remark, that instead of having the two exterior posts over the roof of the building, which might require it to be larger than necessary, they may be made to stand upon beams projecting from its extremities*.

XLVI. Proposal for the Estallishment of a National Museum. By J. S. Duncan, Esq. of Lincoln's Inn.

[Concluded from p. 205.]

$T_{\text {HE:following outlines of tablets, supposed to be affixed }}$ to different parts of an arranged museum, are not offered as a eomplete plan of a museum arranged with a view to the illustration of natural theology, but are sketched slightly, with the view of merely suggesting the practicability of such mode of exhibition.

\section{Varteties of Power. II. Extent of Power.}

A.

1. Attraction. Magnets. Electrometers. Cohering Plates, \&c. Compass.

2. Repulsion. Magnets. Electrometers. Fife-arms, \&c.

3. Impulse. Ivory Balls. Reaction, \&c.

Gravitation appears to be only a particular attraction. Thus, we may say the heavenly bodies are attracted by, or gravitate toward, one another. Some say, all bodies are impelled by external agency in all cases of what is commonly called attraction and repulsion. Of late this has been maindained by Le Sage of Geneva. It is not material to the conclusions of natural theology, whether these be

- For several omissions in the former part of Capt. Pasley's communication, see the end of the present Number of the Phil. Mag.

different 